NBER WORKING PAPER SERIES

\title{
THE HIGH DEMAND FOR INTERNATIONAL RESERVES IN THE FAR EAST: WHAT'S GOING ON?
}

\author{
Joshua Aizenman \\ Nancy Marion \\ Working Paper 9266 \\ http://www.nber.org/papers/w9266 \\ NATIONAL BUREAU OF ECONOMIC RESEARCH \\ 1050 Massachusetts Avenue \\ Cambridge, MA 02138 \\ October 2002
}

This paper was prepared for the Federal Reserve Bank of San Francisco conference on Financial Issues in the Pacific Basin Region, September 26-27, 2002. We wish to thank our discussant, Hali Edison, and the other conference participants for their helpful comments. The views expressed herein are those of the authors and not necessarily those of the National Bureau of Economic Research.

(C) 2002 by Joshua Aizenman and Nancy Marion. All rights reserved. Short sections of text, not to exceed two paragraphs, may be quoted without explicit permission provided that full credit, including (C) notice, is given to the source. 
The High Demand for International Reserves in the Far East: What's Going On? Joshua Aizenman and Nancy Marion

NBER Working Paper No. 9266

October 2002

JEL No. F31, F32, F34

\section{ABSTRACT}

This paper explores econometric and theoretical interpretations for the relatively high demand for international reserves by countries in the Far East and the relatively low demand by some other developing countries. Using a sample of about 125 developing countries, we show that reserve holdings over the 1980-1996 period seem to be the predictable outcome of a few key factors, such as the size of international transactions, their volatility, the exchange-rate arrangement, and political considerations. The estimating equation does a good job of predicting reserve holdings in Asia before the 1997 financial crisis. After the crisis, the estimating equation significantly underpredicts the reserve holdings of several key Far East countries, as one might expect from the Lucas Critique. This under-prediction is consistent with models explaining reserve demand in developing countries. Specifically, we show that sovereign risk and costly tax collection to cover fiscal liabilities lead to a relatively large precautionary demand for international reserves. In the aftermath of a crisis, countries that have to deal with higher perceived sovereign risk and higher fiscal liabilities (both funded and unfunded) will opt to increase their demand for reserves. The models also help us understand why some developing countries do not hold large precautionary reserve balances in the aftermath of crises. Countries with high discount rates, political instability or political corruption find it optimal to hold smaller precautionary balances. We also show that models that incorporate loss aversion predict a relatively large demand for international reserves. Hence, if a crisis increases the volatility of shocks and/or loss aversion, it will greatly increase the demand for international reserves. Consequently, we conclude that the 'puzzling' pattern in international reserve holdings is reasonably explained by the extended models described in this paper.

Joshua Aizenman

Department of Economics

University of California, Santa Cruz

Social Science I

Santa Cruz, CA 95064

and NBER

jaizen@ucsc.edu
Nancy Marion

Department of Economics

Dartmouth College

6106 Rockefeller Hall

Hanover, NH 03755

nancy.marion@dartmouth.edu 


\section{$\underline{\text { Introduction }}$}

In the aftermath of the Asian financial crisis, emerging markets in the Far East have built up large stockpiles of international reserves. Today, China, Taiwan, Hong Kong, South Korea and Singapore rank just behind Japan as the world's biggest holders of international reserves. These five Asian emerging markets together hold reserves totaling nearly US\$700 billion.

There is a growing debate about the need to hold so many reserves. Some critics point out that holding a lot of reserves is costly. Reserves held in dollar-denominated Treasuries, for example, earn a modest return, far below the government's own cost of borrowing either in local currency or in dollars. Why hold cash in the bank and pay high interest on outstanding liabilities? Critics also note that the yield on reserves is much lower than the opportunity cost of those reserves as measured by the potential return on real investments in the economy.

Those who support large reserve balances argue that the cost of holding reserves is small relative to the economic consequences of a crisis. Large stockpiles are needed to forestall-- or at least weather-- currency and financial crises that are increasingly frequent and severe in today's international monetary system. Moreover, just when an emerging market most needs reserves -in a crisis -- it can be shut out of the international capital markets because of sovereign risk concerns. An IMF bailout is not guaranteed, and even when forthcoming, comes with strict conditions. Holding large reserve stockpiles is therefore prudent policy. ${ }^{1}$

In this paper, we examine some of the factors that influence the decision to hold international reserves in developing countries. We also explore why these holdings are

\footnotetext{
${ }^{1}$ In addition, international reserves have traditionally been used to manage fixed exchange rates. Even though a number of countries have moved to more flexible exchange-rate arrangements in the 1990s, some studies suggest that emerging markets still hold large reserve stockpiles to limit exchange-rate volatility, particularly when they have large external liabilities denominated in foreign currency. (Hausmann, et al, 2001; Calvo and Reinhart, 2002).
} 
particularly large in the Far East. We begin with a standard estimating equation that does quite well in predicting central bank reserve holdings through 1996. For a sample of about 125 developing countries, reserve holdings seem to be the predictable outcome of a few key factors, such as the size of international transactions, their volatility, the exchange-rate arrangement, and political considerations. The explanatory variables do a good job of predicting reserve holdings in Asia. If anything, they over-predict reserve holdings for some emerging markets in the Far East over the 1980-1996 period. After the 1997 Asian financial crisis, however, the estimating equation significantly under-predicts the reserve holdings of key Far Eastern countries.

We present two models that illustrate why the recent reserve build up in the Far East may represent precautionary holdings. The first model shows that the desire to smooth consumption and distortions intertemporally in the face of conditional access to global capital markets and costly tax collection generates a large precautionary demand for reserves. Sovereign risk and costly tax collection generate a high demand for reserves even if agents are risk neutral. The model also helps us understand why some developing countries do not hold large precautionary reserve balances in the aftermath of last decade's crises. Countries with high discount rates, political instability or political corruption find it optimal to hold smaller precautionary balances. The second model shows how increased loss aversion and/or increased volatility in the aftermath of a financial crisis can generate a precautionary demand for reserves even when the equity premium is positive.

The rest of the paper is organized as follows. Section 2 describes recent trends in reserve holdings by developing countries and demonstrates that the emerging markets of the Far East are outliers in terms of their sizeable reserve holdings. Section 3 presents a standard estimating equation that does a good job of predicting reserve holdings in a panel of developing countries 
over the 1980-1996 period but fails to capture the tremendous build-up in reserves in the Far East after the Asian crisis. In Section 4 we explore some theories that enhance our understanding of why emerging markets may want to hold large precautionary reserve balances in the aftermath of that crisis. Section 5 presents some concluding thoughts.

\section{Recent Trends in Reserve Holdings by Developing Countries}

At the end of 1994, global reserves (minus gold) were US\$1,254 billion. As shown in Figure 1, half were held by industrial countries and half by developing ones. Among developing countries, Asian economies held the most by far. Asian economies held $30.5 \%$ of global reserves, while Western Hemisphere countries held only 8.3\%, Middle Eastern countries 5.3\%, developing Europe $3.6 \%$ and Africa 1.9\%.

In the past seven and a half years, global reserves have almost doubled in nominal terms, to US\$2,223 billion at the end of May, 2002. Today, developing countries hold the bulk of reserves -- $60.4 \%$ of the total. Asian economies hold an even more commanding lead, having increased their share of global reserves from 30.5\% in 1994 to 38\% at the end of May, 2002. The developing countries in Europe hold the next largest share, but it is much smaller than Asia's, only $7.1 \%$ of total reserves. ${ }^{2}$

\footnotetext{
${ }^{2} \mathrm{We}$ focus on reserves minus gold for three reasons. First, there are concerns on how to value gold. Second, gold now accounts for less than 3\% of global reserve holdings when gold is measured at 35 SDRs per ounce. Third, gold holdings by developing countries are negligible. When we include gold and follow the IMF in valuing it at 35 SDRs per ounce, we find that developing countries held $48.3 \%$ of total reserves in 1994 while Asia held $29.6 \%$. Developing countries held $59.6 \%$ of total reserves in May, 2002, and Asia 37.5\% of the total.
} 
Figure 2 reveals that today's biggest reserve holders are all Asian economies. Japan holds more reserves than any other nation, US $\$ 411.6$ billion at the end of May, 2002. China is second, with US\$241.9 billion in reserve holdings. Next in order come Taiwan (US\$139.8 billion), Hong Kong (US\$111.2 billion), South Korea (US\$109.6 billion) and Singapore (US\$78 billion).

Figures 3-7 provide additional details about the reserve holdings of these Asian countries (except Japan). ${ }^{3}$ In order to get a sense of magnitudes and to facilitate comparisons across countries, we have scaled reserve holdings by a number of different measures, such as weeks of import cover, GDP, M2, and, when available, total external debt and total short-term external debt. For example, the plots in Figure 3 show that China has increased its reserve holdings since 1985 regardless of how reserves are scaled. In terms of weeks of import cover, China's reserves have more than doubled over the 1985-2000 period. As a share of GDP they have quadrupled. As a share of short-term external debt, they have quintupled. As a share of M2 or total external debt, reserves have also increased over the 1985-2000 period, but more modestly. China's reserve holdings in the 1997-2000 period have been the largest in its history for all scaling measures except M2.

Hong Kong and South Korea follow the same pattern as China. Reserves have increased over the 1985-2000 period regardless of scaling measure, and the increase has been most pronounced in the aftermath of the Asian financial crisis. For Korea, the recent growth in reserves is quite dramatic, whether reserves are scaled by weeks of imports, GDP, M2, or

\footnotetext{
${ }^{3}$ The reasons for Japan's large reserve holdings are not addressed in this paper, since our empirical and theoretical focus will be on the reserve holdings of developing countries.
} 
external debt. Interestingly, Korea's reserves are not yet equal to its total external debt. In contrast, China's reserve holdings exceeded total external liabilities by the end of $1999 .^{4}$

Taiwan and Singapore show a somewhat different pattern. Both have maintained considerable reserve holdings for an extended period of time. We therefore do not see the big build-up in reserve holdings that occurred in other Asian economies following the Asian financial crisis.

The pattern in reserve holdings is striking. Developing countries, and specifically emerging markets in the Far East, hold an increasing share of global reserves. The world's top reserve holders are all located in Asia. Using a number of scaling measures, Asian emerging markets hold record levels of reserves today. What is going on?

\section{Estimating Reserve Holdings - How Well Do We Predict For Asian Economies?}

We wish to estimate reserve holdings for a panel of developing countries and examine whether the estimation performs well in predicting reserves for the Asian emerging markets both in sample and out-of-sample.

We start with a standard estimating equation, where reserve holdings depend on scale factors, international transactions volatility, and openness. The latter variable is a proxy for the country's vulnerability to external shocks. Thus our estimating equation in log-linear form is:

\footnotetext{
${ }^{4}$ China's large and growing stock of international reserves may be due to concerns about the solvency of its banking system more than the size of its external debt. In May, 2002, China's Central Bank Governor said that $25-30 \%$ of all bank loans were not being repaid. The creditrating agency Standard \& Poor's estimated that the situation might be twice as bad, with half of all loans classifiable as non-performing. (Wall Street Journal, May 10, 2002.)
} 
$\ln \left(\frac{R_{i t}}{P_{i t}}\right)=\alpha_{0}+\alpha_{1} \ln \left(p o p_{i t}\right)+\alpha_{2} \ln \left(g p c_{i t}\right)+\alpha_{3} \ln \left(e x a_{i t}\right)+\alpha_{4} \ln \left(i m y_{i t}\right)+\alpha_{5} \ln \left(n e e r_{i t}\right)+\varepsilon_{t}$

where $R$ is actual holdings of reserves minus gold, valued in millions of U.S. dollars and deflated by the U.S. GDP deflator $(P)$, pop is the total population of the country, $g p c$ is real GDP per capita, exa is the volatility of real export receipts, imy is the share of imports of goods and services in GDP, and neer is the volatility of the nominal effective exchange rate.

Real reserve holdings should increase with the size of international transactions, so we would expect reserve holdings to be positively correlated with the country's population and standard of living. Reserve holdings should increase with the volatility of international receipts and payments if they are intended to help cushion the economy, so we would expect reserve holdings to be positively correlated with the volatility of a country's export receipts. Reserve holdings should also increase with the vulnerability to external shocks. We therefore expect reserve holdings to be positively correlated with the average propensity to import, a measure of the economy's openness and vulnerability to external shocks. Finally, since greater exchangerate flexibility should reduce the demand for reserves because central banks no longer need a large reserve stockpile to manage a fixed exchange rate, reserve holdings should be negatively correlated with exchange-rate volatility. ${ }^{5}$

\footnotetext{
${ }^{5}$ In theory, reserve holdings should also be negatively correlated with the opportunity cost of holding them. The opportunity cost is often measured by the spread between the country's own bond yield and the return on U.S. Treasury bills. Previous studies have found that it is not a significant explanatory factor. (See Flood and Marion (2002) and the references cited there.) Moreover, interest-rate data have not been available for many developing countries until quite recently.
} 
Table 1 presents two regressions for a panel consisting of 122 developing countries over the 1980-96 period. $^{6}$ Regression (1) confirms our priors. The scale variables, population size and real GDP per capita, are positive and highly significant. The volatility of real export receipts and the vulnerability to external shocks measured by openness are also positive and highly significant. Greater exchange-rate variability significantly reduces reserve holdings. These five variables account for 88 percent of the variation in actual reserve holdings when country fixed effects are included; they account for over 70 percent of the variation without the fixed effects. ${ }^{7}$

Regression (2) in Table 1 adds some political measures to the explanatory variables used in regression (1). Aizenman and Marion (2002) show that political uncertainty and political corruption each act as a tax on the return to reserves and hence reduce optimal holdings. Regression (2) illustrates this point for a smaller sample of countries for which we have political measures. An increase in an index of political corruption (corrupt) significantly reduces reserve holdings, as does an increase in the probability of a government leadership change by constitutional means $(p o l){ }^{8}$

Figures 8-10 use Regression (1), the estimation without political variables, to illustrate how well our five explanatory variables predict reserve holdings for various geographical regions and for specific emerging markets. To obtain the figures, we first compute the average (nonweighted) value of the coefficients on the country dummies. The average coefficient value is -0.2573 . We then compute one, two and three standard deviations around this average. These

\footnotetext{
${ }^{6}$ See the data appendix for details about the regression variables and country sample.

${ }^{7}$ We also experimented with adding a measure of financial openness, but it did not have a significant effect.

${ }^{8}$ The political corruption data is from Tanzi and Davoodi (1997). The political uncertainty measure was obtained from Leblang (2000).
} 
values are shown as gridlines in the figures. Finally, we compute the average value of the coefficients on country dummies for various geographical regions of the world, using the IMF's regional classification, and we also plot the coefficient on the country dummy for specific emerging markets of interest.

An examination of Figure 8 shows that when we estimate reserve holdings without explanatory political variables, our predictions for the broad regions of Asia, Latin America and Africa are quite good. The average values of the coefficients for these regions are close to the sample average. However, for the smaller sample of Far East emerging markets (China, Indonesia, Korea, Malaysia, Philippines and Thailand) and Latin American emerging markets (Argentina, Brazil, Chile, Colombia, Mexico, Peru, Uruguay, and Venezuela), average coefficient values are considerably more negative than the sample average. Consequently, the regression's explanatory variables over-predict reserve holdings for these subsets of countries in the $1980-96$ period.

Figures 9 and 10 illustrate the extent of over-prediction for each of the countries in these two regions. In the Far East, the coefficient on China's dummy is two standard deviations below the average, while the coefficients on Indonesia, Korea, the Philippines and Thailand are all below the average by at least one standard deviation. In Latin America, no country has a coefficient more than two standard deviations below the average, though Brazil comes close.

Figures 11-13 repeat the exercise for estimates derived from Regression (2), the one that includes political variables. In Figure 11 we see that the average values of the dummy coefficients for Latin America and Africa are close to the sample average of 0.102. The average value for Asia is more negative but still within one standard deviation of the average. However, when we examine specific countries in Figures 12-13, we see that the coefficient on the country 
dummy is more than two standard deviations below the average for Korea and Brazil, again suggesting that the explanatory variables inclusive of political factors are over-predicting reserve holdings for these important emerging markets.

Figure 14 shows the deviation of each country's dummy coefficient from the sample average for both regression (1) and (2). One can see specific outliers, both positive and negative. For example, when political variables are considered, the biggest negative outliers are Brazil, Cote d'Ivoire, South Korea and South Africa. The dummy coefficients for these countries are more than two standard deviations below the average. China and Mexico have dummy coefficients more than one standard deviation below the average.

We now use data for 1997-1999 to check how well our two regressions predict out-ofsample for the Asian emerging markets. ${ }^{9}$ Table 2 displays the results.

For Korea, the regression that includes the political variables continues to over-predict reserve holdings for 1997, the year of Korea's financial crisis. However, the regression dramatically under-predicts Korea's reserve holdings in both 1998 and 1999. The estimation under-predicts Korea's reserve holdings by $\$ 14.6$ billion in 1998 and by $\$ 25.8$ billion in 1999 . The 1999 prediction error is 37 percent of actual reserves. ${ }^{10}$ These findings suggest that the 1997-98 Asian financial crisis increased Korea's optimal long-run demand for reserves. ${ }^{11}$ With

\footnotetext{
${ }^{9}$ We do not have corruption and political instability data for the 1997-99 period, but since these data change slowly, if at all, over the 1990s, we just extrapolate forward using the political data from 1996.

${ }^{10}$ These prediction errors are expressed in real terms. If there were no prediction errors on price deflators, the under-prediction of Korean reserves would be $\$ 15.3$ billion in nominal terms in 1998 and $\$ 27.5$ billion in 1999 .

${ }^{11}$ In the next section, we examine several reasons for the increase in optimal reserve holdings.
} 
limited access to global capital markets following the crisis, Korea could not immediately adjust its stock to the higher optimal level. ${ }^{12}$

For the other emerging Asian economies, the gap between the actual and predicted value of reserves over the 1997-99 period is less dramatic in absolute terms though not always in percentage terms. In the case of China, the regression with political variables included underpredicts China's reserve holdings in real terms in 1997 and 1998 by $\$ 12$ billion and $\$ 11.4$ billion, respectively, while it over-predicts China's reserve holdings in 1999 by $\$ 12.3$ billion. The estimation under-predicts Thailand's reserve holdings in all three years, 1997-1999, with the greatest under-prediction being $\$ 10$ billion in real terms in 1999. That prediction error represents 31 percent of actual reserves. The estimation also under-predicts Philippine reserve holdings in all three years as well, with the 1999 under-prediction being the largest, at $\$ 6.9$ billion, or 55 percent of the actual level. Interestingly, the estimation over-predicts Malaysian reserve holdings in all three years, with the largest over-prediction being $\$ 16$ billion in crisis year 1997. The Malaysian results suggest a possible trade off between the willingness to adopt capital controls and the willingness to hold international reserves. Because Malaysia chose to impose capital controls during the financial crisis, it reduced its effective integration with the global capital markets and its demand for international reserves. ${ }^{13}$

\footnotetext{
${ }^{12}$ Evaluating empirically the impact of access to global capital markets on the demand for international reserves may be subject to a "peso problem" -- access matters most when a crisis hits. A regression using data with infrequent or shallow crises will under-estimate the increase in reserve demand following a severe crisis.

${ }^{13}$ The regression with political variables included also under-predicts out-of-sample for some emerging markets in Latin America. For example, it under-predicts Brazil's reserve holdings by $\$ 23.1$ billion, $\$ 16.7$ billion and $\$ 11.7$ billion in years 1997-99, respectively, and under-predicts Mexico's reserve holdings by $\$ 8.4$ billion, $\$ 9.7$ billion and $\$ 8.8$ billion in those same years. The regression does better out-of-sample for Chile, over-predicting its reserve holdings by a mere $\$ 0.5$ to $\$ 3$ billion.
} 
Based on our data analysis, we conclude that a standard estimating equation does well in predicting Asian reserve holdings in the 1980-1996 period. If anything, the explanatory variables over-predict reserve holdings for some Far East countries. However, the equation mostly under-predicts reserve holdings for countries in the Far East post-1996. These observations suggest that behavior has changed since the Asian financial crisis. In the next section, we put forward some hypotheses for why reserve holdings in the Far East have increased so much in recent years.

\section{Some Reasons for Large Reserve Holdings}

The recent build-up of large international reserve holdings in a number of Asian emerging markets may represent precautionary holdings. While these holdings are undoubtedly motivated by many factors, we focus on two. The first is the need to smooth consumption and distortions intertemporally in the face of conditional access to global capital markets and costly domestic tax collection. The second is an increase in the volatility of shocks and/or loss aversion after the 1997-98 Asian financial crisis. Since these motivating factors could induce all emerging markets to hold large precautionary balances, why is it that some do not? We show that countries with relatively high discount rates, political instability, or political corruption find it optimal to hold less precautionary reserves.

We now examine in turn the roles of conditional access to global capital markets and loss aversion. 


\section{a. Conditional access to global capital markets}

The demand for international reserves is frequently analyzed in terms of a buffer stock model. That model suggests central banks should choose a level of reserves to balance the macroeconomic adjustment costs incurred in the absence of reserves with the opportunity cost of holding reserves. An alternative strategy is to view international reserve holdings as a form of precautionary saving for economies with conditional access to global capital markets and costly domestic tax collection. Even if consumers are risk neutral, these considerations can be important enough to generate a positive and potentially large stockpile of international reserves. Formally, both costly taxation and imperfect integration with the global capital market due to sovereign risk generate non-linearities that make precautionary balances welfare-improving.

To simplify our example, we assume agents are risk neutral. (Recall that risk-neutral agents choose no precautionary saving in the conventional analysis.) Focusing on risk neutrality allows us to isolate the effects of non-linearities introduced by imperfect capital markets and costly taxation.

We study a two-period, two-states-of-nature model of an emerging-market economy. The economy is subject to productivity shocks that create a volatile tax base. It faces inelastic fiscal outlays and finds it costly to collect taxes. The economy can borrow internationally in the first period, but because there is some chance it will default in the second period, it faces a credit ceiling. $^{14}$

The central bank actively targets the stock of reserves. Even so, a variety of exchangerate arrangements are possible, such as a fixed exchange rate or a managed float, because the

${ }^{14}$ A detailed model along these lines is described in Aizenman and Marion (2002). The model described here is a simplified version of that model. 
balance sheets of the central bank and treasury are consolidated and the net taxes paid by consumers are determined as a residual. ${ }^{15}$

Suppose $\varepsilon$ is a productivity shock that occurs only in the second period. Then GDP in period $\mathrm{i}(\mathrm{i}=1,2)$ is

(2) $\quad Y_{1}=1 ; \quad Y_{2}=\left\{\begin{array}{lll}1+\varepsilon & \text { with probability } & 0.5 \\ 1-\varepsilon & \text { with probability } & 0.5\end{array}\right.$

The emerging market can borrow in international capital markets. It borrows $B$ in period 1 at a contractual rate $r$ and owes $(1+r) B$ in period 2. If it faces the bad productivity shock in the second period, it defaults. Default is not without penalty, however. International creditors can confiscate some of the emerging market's export revenues or other resources equal to a share $\alpha$ of its output. The more open the economy, the greater $\alpha$ is likely to be. We assume that the defaulting country's international reserve holdings are beyond the reach of creditors. ${ }^{16}$

In the second period, the country repays its international obligations if repayment is less costly than the default penalty. The country ends up transferring $S_{2}$ real resources to international creditors in the second period, where:

$$
S_{2}=\operatorname{MIN}\left[(1+r) B ; \alpha Y_{2}\right], \quad 0<\alpha<1
$$

${ }^{15}$ This structure would also apply to the operation of export stabilization funds, such as Chile's copper fund.

${ }^{16}$ This is a realistic assumption. For example, on January 5, 2002, The Economist reported "[President Duhalde] confirmed that Argentina will formally default on its debt, an overdue admission of an inescapable reality. The government has not had access to international credit (except from the IMF) since July. It had already repatriated nearly all of its liquid foreign assets to avoid their seizure by creditors." (The Economist, p. 29) 
Suppose the risk-free interest rate is $r_{f}$. The interest rate attached to the country's acquired debt, $r$, is determined by the condition that the expected return on the debt is equal to the risk-free return:

$$
E\left[S_{2}\right]=\left(1+r_{f}\right) B
$$

Applying the above assumptions and recognizing that $E\left[S_{2}\right]=0.5(1-\varepsilon) \alpha+0.5(1+r) B$, we infer that the supply of fund facing the economy is

$$
r= \begin{cases}r_{f} & \text { for } \quad B \leq \frac{(1-\varepsilon) \alpha}{1+r_{f}} \\ 1+2 r_{f}-\frac{(1-\varepsilon) \alpha}{B} & \text { for } \quad \frac{(1-\varepsilon) \alpha}{1+r_{f}} \leq B \leq \frac{\alpha}{1+r_{f}}\end{cases}
$$

The demand for public goods, such as health, pensions, and defense, is assumed to be completely inelastic and set at $\bar{G}$. Public goods expenditures are financed, in part, by tax revenues. Collecting taxes is assumed to be costly. Costs include direct collection and enforcement costs as well as indirect deadweight losses associated with the distortions induced by taxes. Like Barro (1979), we model these costs as a non-linear share of output and let them depend positively on the tax rate. Thus, a tax at rate $t$ yields net tax revenue of

$$
T(t)=Y\left[t-0.5 \lambda t^{2}\right]
$$

The term $0.5 \lambda t^{2}$ measures the fraction of output lost because of inefficiencies in the tax collection system. For a given net tax revenue $T_{i} ; i=1,2$, the needed tax rate is 


$$
t_{i}\left(\xi_{i}\right)=\frac{1-\sqrt{1-2 \lambda \xi_{i}}}{\lambda},
$$

where $\xi_{i}=\frac{T_{i}}{Y_{i}} ; \quad i=1,2$ denotes the effective tax rate from the consumers' point of view.

The government can acquire international reserves in the first period, let them earn the risk-free rate, and spend them in the second period. One way of acquiring reserves is through sovereign borrowing. Even if reserves are acquired as the counterpart of private-sector borrowing, full sterilization by the central bank implies an ultimate swap of sovereign debt for reserves. Another way of accumulating reserves is through taxation. Higher taxes depress domestic absorption and generate a bigger current-account surplus in the first period. In the second period, reserves may be spent to finance repayment of the international debt and government expenditures. In a two-period model, there is no need to hold reserves beyond the second period. Thus the terminal demand for reserves is zero.

The government faces the following budget constraints:

$$
\begin{aligned}
& T_{1}=\bar{G}+R-B ; \\
& T_{2, h}=\bar{G}+B(1+r)-\left(1+r_{f}\right) R ; \quad T_{2, l}=\bar{G}+\alpha(1-\varepsilon)-\left(1+r_{f}\right) R
\end{aligned}
$$

where $T_{2, h} ; \quad T_{2, l}$ correspond to net taxes in the second period when output is high and low, respectively. In the first period, taxes and foreign borrowing must finance spending on public goods and reserve accumulation. In the second period, spending on public goods and debt repayments must be financed by taxes and available reserves. 
We now wish to evaluate the optimal foreign borrowing and demand for international reserves by a country with a costly tax collection system and some chance of defaulting. Subject to the government budget constraints in (8), the policy maker chooses the foreign debt and international reserves to acquire in the first period in order to maximize the intertemporal utility of risk-neutral consumers:

$$
\underset{B, \mathrm{R}}{\operatorname{Max}}\left\{1-\mathrm{t}_{1}+\frac{0.5}{1+\rho}\left[(1+\varepsilon)\left(1-t_{2, h}\right)+(1-\varepsilon)\left(1-t_{2, l}\right)\right]\right\}
$$

where $\rho$ is the discount rate. Consumer spending in each period is merely output net of taxes, where taxes include collection costs. Applying (8), the effective tax rate facing consumers in each period is:

$$
\xi_{1}=\bar{G}+R-B ; \quad \xi_{2, h}=\frac{\bar{G}+B(1+r)-\left(1+r_{f}\right) R}{1+\varepsilon} ; \quad \xi_{2, l}=\frac{\bar{G}+\alpha(1-\varepsilon)-\left(1+r_{f}\right) R}{1-\varepsilon}
$$

Suppose that external borrowing occurs in the range where sovereign risk applies. (Our solution will later identify this range.) The first-order condition that determines optimal borrowing is:

$$
\frac{1}{\sqrt{1-2 \lambda \xi_{1}}}=\frac{1+r_{f}}{1+\rho}\left[\frac{1}{\sqrt{1-2 \lambda \xi_{2, h}}}\right]
$$


Note that (7) implies that the marginal cost of public funds (the drop in disposable income needed to increase net taxes by one dollar) is ${ }^{17}$

$$
-\frac{d\left[Y_{i}\left(1-t_{i}\right)\right]}{d T_{i}}=\frac{1}{\sqrt{1-2 \lambda \xi_{i}}} .
$$

Applying (11) and (12), we infer that optimal borrowing equates the expected second-period marginal cost of public funds evaluated over the distribution of shocks that induce full repayment to the cost of public funds in the first period. Condition (11) implies that external borrowing alone is insufficient for achieving intertemporal smoothing of the tax burden in all states of nature. If a bad shock reduces future output and the country defaults, then the absence of international reserves to finance second-period public expenditures implies the country must raise taxes to finance them.

The first-order condition that determines optimal first-period reserve holdings is:

$$
\frac{1}{\sqrt{1-2 \lambda \xi_{1}}}=0.5 \frac{1+r_{f}}{1+\rho}\left[\frac{1}{\sqrt{1-2 \lambda \xi_{2, h}}}+\frac{1}{\sqrt{1-2 \lambda \xi_{2, l}}}\right]
$$

Reserves are chosen optimally to equate the expected present value of the marginal cost of public funds in the two periods. They permit expected smoothing of the tax burden over time.

Applying (11) and (13) we find

$$
\xi_{2, h}=\xi_{2, l}
$$

\footnotetext{
${ }^{17}$ In order to obtain (11), we use the observation that $d[B(1+r)] / d B=2\left(1+r_{f}\right)$ that follows from (5).
} 


$$
\left[\frac{1+\rho}{1+r_{f}}\right]^{2}-1=\frac{2 \lambda}{1-2 \lambda \xi_{2, h}}\left[\xi_{2, h}-\xi_{1}\right] .
$$

The combination of optimal borrowing and optimal reserve holdings equalizes the cost of public funds across the future two states of nature. [See (14).] The gap between the subjective time preference and the risk free interest rate determines the intertemporal profile of the costs of public funds. The greater the bias towards present consumption, the greater the bias towards lower present tax rates. This bias, in turn, increases borrowing (B) and reduces saving (R).

A useful benchmark case is one where the intertemporal bias is zero $\left(r_{f}=\rho\right)$. In this case, the tax rate is equalized across time and across the two future states of nature. Applying (14)-(15) to this benchmark case we find:

$$
B=R=\frac{\varepsilon \bar{G}+\alpha(1-\varepsilon)}{1+\rho} .
$$

The result in (16) yields several insights. First, the demand for reserves and external borrowing each depend linearly and positively on the size of fiscal commitments and on a measure of openness ( $\bar{G}, \alpha$, respectively). They also depend on the variability of shocks $(\varepsilon)$. This result contrasts with a conventional precautionary demand that depends on the square of the variation. Hence, the size of precautionary reserve holdings in our example is potentially large. If $\bar{G}$ is interpreted to include the now explicit government liabilities to banks and other institutions in the aftermath of a financial crisis, then the demand for reserves after a crisis could be quite large. 
A second insight is that the net borrowing position, $\mathrm{B}-\mathrm{R}$, increases with the bias towards present consumption, $\rho-r_{f} \cdot{ }^{18}$ This result is illustrated in Figure 15, where a simulation traces the dependence of optimal borrowing and international reserves on the subjective discount rate. A greater bias towards early consumption tilts the tax rate towards the future. To satisfy the budget constraints, international reserve holdings must fall and external borrowing must rise, increasing the country's net borrowing position.

Third, the result that choosing reserve holdings and external borrowing optimally accomplishes tax smoothing between various states is the outcome of having only three states of nature -- one realization of first-period output and two possible realizations of the second-period output. If there were more than three state of nature but no additional financial instruments, complete tax smoothing could not occur. Yet even in that environment, holding international reserves as well as external debt would allow better tax smoothing because it would smooth the expected tax burden across periods.

In Aizenman and Marion (2002), we examine the contribution of reserves and external debt to tax smoothing for the case where the second-period productivity shock has a continuous distribution and agents may be risk averse. We also show that political uncertainty and political corruption each tax the return on reserves, reducing optimal reserve holdings and increasing external borrowing. In our simplified example here, the effect of increasing the bias toward present consumption is very similar to the effect of political uncertainty or corruption. As shown in Figure 1, it increases the net borrowing position, B - R. The bias towards present

\footnotetext{
${ }^{18}$ For the case where the risk-free interest rate is zero, the condition for having an internal solution with a partial default is that the government expenditure not be 'too large'-- $\alpha>\bar{G}$. A large enough fiscal demand would induce a corner solution where borrowing is at the credit ceiling.
} 
consumption, like political uncertainty or corruption, may cause some countries to hold fewer precautionary reserve balances than would otherwise be the case.

Fourth, the results are the outcome of two features interacting with each other, costly taxation and conditional access to the global capital markets induced by sovereign risk. It is easy to verify that we need both features to obtain a meaningful demand for reserves and external borrowing. If the probability of default is zero or if taxes are lump sum, the solution identifies only the net debt, $\mathrm{B}-\mathrm{R}$, because borrowing and reserve depletion are perfect substitutes.

\section{b. Loss aversion}

Loss aversion is the tendency of agents to be more sensitive to reductions in their consumption than to increases, relative to some reference point. It is modeled using a generalized expected utility framework that attaches bigger weights to 'bad' states of nature and smaller ones to 'good' states than in the conventional expected utility set up. Loss aversion has important implications for the size and the benefits of buffer stocks. An optimizing policy authority may choose a small buffer stock if it is maximizing the expected utility of agents with conventional preferences. It will choose a much larger buffer stock if it is maximizing the utility of loss-averse agents. [See Aizenman (1998).] Consequently, our focus on a non-linearity in preferences induced by loss aversion complements our previous examination of conditional access to global capital markets and costly tax collection, where different non-linearities generated a demand for precautionary reserve holdings.

Even though loss aversion provides an incentive for holding substantial international reserves, critics argue that large reserve holdings waste resources. The opportunity cost of holding reserves in safe, low-return assets is not having those funds channeled to capital 
formation, a higher return activity. ${ }^{19}$ We evaluate this criticism and show that even when there is a sizeable equity premium, such that the return on domestic capital far exceeds the return on the safe asset, it can still be optimal to hold large reserve balances if agents are loss-averse. We illustrate the point using a simple two-period example.

Consider the case where initial income, Z, is allocated across international reserves $(\mathrm{R})$, investment in tangible capital (I), and consumption (C). International reserves earn a relatively low but risk-free real interest rate, $r_{f}$. Their opportunity cost is the forgone return on risky domestic capital. The intertemporal budget constraints imply that consumption in periods 1 and 2 are:

$$
C_{1}=Z-R-I
$$

$$
C_{2}=f(K+I)(1+\varepsilon)+R\left(1+r_{f}\right)
$$

where $f(K+I)(1+\varepsilon)$ is a neoclassical production function, $\mathrm{K}$ is the initial stock of capital, and $\varepsilon$ is a second-period productivity shock. Note that reserves boost consumption in the second period.

To simplify, suppose there are only two future states of nature. There is an equal chance of the productivity shock being good or bad:

$$
\varepsilon=\left\{\begin{array}{lll}
+\delta & \text { with probability } & 0.5 \\
-\delta & \text { with probability } & 0.5
\end{array} .\right.
$$

${ }^{19}$ One rebuttal has been to suggest that some fraction of a country's reserves could be held in riskier, higher-return assets. See Feldstein (2002). 
Private agents choose a level of domestic investment spending and the policy authority chooses a stock of international reserves to maximize the utility (V) of loss-averse agents:

$$
\begin{aligned}
& M A X \quad V \\
& I, R
\end{aligned}
$$

where

$$
\begin{aligned}
& V=u_{1}+\frac{0.5}{1+\rho}\left[(1-\theta) u_{2, H}+(1+\theta) u_{2, L}\right] ; \\
& u_{1}=u(Z-R-I) ; \quad u_{2, H}=u\left(f(K+I)(1+\delta)+R\left(1+r_{f}\right)\right) ; \\
& u_{2, L}=u\left(f(K+I)(1-\delta)+R\left(1+r_{f}\right)\right) .
\end{aligned}
$$

In (19), the extent of loss aversion is captured by the extra weight $(\theta)$ attached to the bad state of nature in the utility function $(V)$. The loss aversion ratio is the marginal utility of a loss relative to the marginal utility of a gain. It is equal to $(1+\theta) /(1-\theta)$. The ratio measures the tendency of agents to be more sensitive to reductions in their utility than to increases. [See Tversky and Kahneman (1991) and Kahneman, Knetsch and Thaler (1990)]. The ratio has a value of one in the conventional utility framework where agents assign no extra weight to bad outcomes, but it exceeds one for agents exhibiting first-order loss aversion. Empirical estimates of the loss-aversion ratio are typically in the neighborhood of 2 (corresponding to a weight of $\theta=1 / 3)$.

The marginal product of capital, which is also the opportunity cost of holding reserves, is obtained from one of the first-order conditions of the optimization problem. Loss-averse agents choose their optimal investment spending level when $\mathrm{R}=0$ in order to maximize their utility:

$$
\left.\frac{\partial V}{\partial I}\right|_{R=0}=0
$$


The corresponding first-order condition can be reduced to

$$
M U_{1}=\frac{0.5}{1+\rho}\left[(1-\theta) M U_{2, H}(1+\delta)+(1+\theta) M U_{2, L}(1-\delta)\right] \frac{d f}{d I} .
$$

where $\frac{d f}{d I}$ is capital's marginal product.

The utility gain associated with acquiring the first unit of international reserves is:

$$
\frac{\partial V}{\partial R}=-M U_{1}+\frac{0.5\left(1+r_{f}\right)}{1+\rho}\left[(1-\theta) M U_{2, H}+(1+\theta) M U_{2, L}\right]
$$

The demand for international reserves is positive if obtaining a unit of reserves increases utility. Applying (21) to (22), we infer that the demand for international reserves is positive iff

$$
\left.\frac{\partial V}{\partial R}\right|_{R=0}=\frac{0.5}{1+\rho}\left\{\begin{array}{l}
\left(1+r_{f}-\frac{d f}{d I}\right)\left[(1-\theta) M U_{2, H}+(1+\theta) M U_{2, L}\right]+ \\
\delta \frac{d f}{d I}\left[(1+\theta) M U_{2, L}-(1-\theta) M U_{2, H}\right]
\end{array}\right\}>0
$$

Suppose that the productivity shock $(\delta)$ is small. Then a first-order approximation of secondperiod marginal utility as a function of $\delta$ gives

$$
\left.M U_{2, H} \cong u^{\prime}\right|_{\delta=0}+\left.\delta f(K+I) u^{\prime \prime}\right|_{\delta=0} ;\left.\quad M U_{2, L} \cong u^{\prime}\right|_{\delta=0}-\left.\delta f(K+I) u^{\prime \prime}\right|_{\delta=0} .
$$

Applying (24) to (23) and collecting terms, we find that a first-order approximation of the marginal gain from accumulating reserves around $\mathrm{R}=0$ is 


$$
\left.\frac{\partial V}{\partial R}\right|_{R=0} \cong \frac{\left.u^{\prime}\right|_{\delta=0}}{1+\rho}\left\{-\kappa(1+\theta \delta \phi)+\theta \delta \frac{d f}{d I}\right\}
$$

where $\kappa=\frac{d f}{d I}-\left(1+r_{f}\right)$ and $\phi=-\frac{u^{\prime \prime}}{u^{\prime}} f(K+I)$. The term $\kappa$ denotes the equity premium, while $\phi$ is the coefficient of relative risk aversion.

Examination of (25) shows that if agents have the conventional expected utility $(\theta=0)$, there is no demand for international reserves when the equity premium is positive. ${ }^{20}$ When agents are loss-averse, having reserves reduces losses in bad states. Reserves generate extra gains proportional to $\theta \delta$, where $\theta$ is the aversion to downside loss and $\delta$ is the variation of shocks. If the product $\theta \delta$ is large enough, the demand for international reserves is positive. ${ }^{21}$ Thus a policy authority maximizing the expected utility of loss-averse agents may find it optimal to hold sizeable international reserves even if the equity premium is significantly positive.

In these circumstances, the optimal demand for reserves is determined by solving simultaneously

$$
\frac{\partial V}{\partial R}=\frac{\partial V}{\partial I}=0
$$

${ }^{20}$ This follows from the fact that $\left.\operatorname{sign} \frac{\partial V}{\partial R}\right|_{R=0 ; \theta=0} \cong-\operatorname{sign}\{\kappa\}$. One must qualify this statement somewhat because (25) is a first-order approximation. The more precise statement is to say that the gain from obtaining reserves when $\theta=0$ is of a second-order magnitude, proportional to $\delta^{2}$. Indeed, one can show that in these circumstances, optimal reserves are proportional to $\delta^{2}\left(\mathrm{u}^{\prime \prime} / \mathrm{u}\right.$ ').

${ }^{21}$ The precise condition is $\theta \delta \frac{d f}{d I}>\kappa(1+\theta \delta \phi)$. 
Optimal reserve holdings will be proportional to $\theta \delta$ as well. Consequently, an increase in loss aversion $(\theta)$ and/or an increase in the volatility of shocks $(\delta)$ boost precautionary reserves.

\section{Conclusion}

A standard estimating equation that focuses on a parsimonious set of explanatory factors does a good job in explaining central bank reserve holdings of developing countries through 1996, but it under-predicts reserve holdings of countries in the Far East after that. Undoubtedly, the recent large build-up of international reserve holdings in the Far East is motivated by the experience of the recent Asian financial crisis. Countries facing increased sovereign risk and high taxation costs associated with large inelastic fiscal liabilities find it optimal to hold large precautionary reserve balances. When countries attach more weight to bad outcomes than to good ones, they also find it optimal to hold sizeable precautionary balances of international reserves, even if the opportunity cost is significantly positive. Not all developing economies, indeed not all emerging markets, will hold large reserve stockpiles in the aftermath of crises, however. Countries that strongly favor current consumption, that experience political instability, or suffer from political corruption face a lower effective return on holding reserves and will acquire more modest stockpiles.

Our analysis highlights several new themes. First, political-economy considerations are useful in improving the explanatory power of econometric models of international reserves. Second, the demand for international reserves by emerging markets can be explained by a generalized precautionary saving model, allowing for limited integration with international capital markets, costly tax collection, and relatively inelastic fiscal outlays. These factors explain 
the high demand for international reserves even if agents are risk neutral. While such a model is a useful framework for understanding the issues involved, our paper does not provide a formal test of this model. Indeed, a hybrid model combining adjustment costs and precautionary saving may provide a better interpretation of some of the relevant issues.

In our estimation of the demand for reserves, we experimented with various measures of commercial and financial openness but surprisingly found only the commercial measures to be significant. Our findings may be due to the limited information content of readily available measures of financial integration. Our hope is that better measures of financial integration can improve our understanding of the determinants of reserve demand. ${ }^{22}$

While our analysis focused on the demand for international reserves, we recognize that equilibrium reserve holdings in the Far East are determined by supply-side factors as well, such as the willingness of the United States to supply international liquidity through its currentaccount deficits and the willingness of foreign creditors to finance investments in the Far East. ${ }^{23}$ Taking these factors as exogenous, we focused on explaining the heterogeneity in the demand for international reserves among developing countries in light of these and other exogenous events.

While our study is consistent with the view that hoarding international reserves may serve a useful role, it does not follow that all countries will benefit from adopting this strategy. First, to the extent that hoarding reserves provides a signal of prudence and stability, an aggressive attempt to use this signal by politically unstable or corrupt regimes may be welfare reducing. Those countries would be better advised to deal with underlying institutional

\footnotetext{
${ }^{22}$ See Edison (2001) and Chinn (2002) for some newly proposed measures of financial openness.

${ }^{23}$ See McKinnon (2001) for a recent analysis of some of these factors.
} 
weaknesses. Second, while our model suggests that stabilization funds may be beneficial, it also suggests that their benefits accrue only when countries optimally control both the saving of precautionary reserves and external borrowing. Attempts to focus only on the reserves side may disappoint if the borrowing side is abused as a result of political uncertainty or corruption. Attempts to explore these issues are left for future work. 


\section{References}

Aizenman, Joshua (1998) "Optimal Buffer Stocks and Precautionary Savings with Disappointment Aversion," Journal of International Money and Finance, 17, 931-947.

Aizenman, Joshua and Nancy Marion (2002). "International Reserve Holdings with Sovereign Risk and Costly Tax Collection,” NBER Working Paper 9154, September.

Barro, Robert (1979). "On the Determination of the Public Debt," Journal of Political Economy $87,940-971$.

Calvo, Guillermo and Carmen Reinhart (2002). "Fear of Floating", Quarterly Journal of Economics 117(2), 379-408.

Chinn, Menzie and Hiro Ito (2002). "Capital Account Liberalization, Institutions and Financial Development: Cross Country Evidence,” NBER Working Paper No. 8967, June.

Edison, Hali and Frank Warnock (2001), "A Simple Measure of the Intensity of Capital Controls," International Finance Discussion Paper No. 708, Board of Governors of the Federal Reserve System.

Feldstein, Martin (2002). "Economic and Financial Crises in Emerging Market Economies: Overview of Prevention and Management," NBER Working Paper No. 8837, March.

Flood, Robert and Nancy Marion (2002). "Holding International Reserves in an Era of High Capital Mobility," Brookings Trade Forum 2001, Washington, DC: Brookings Institution, 2002.

Hausmann, Ricardo, Ugo Panizza and Ernesto Stein (2001). "Why Do Countries Float the Way They Float?” Journal of Development Economics 66 (2), 387-414.

Kahneman, D., J. Knetsch, and R. Thaler (1990) "Experimental Tests of the Endowment Effect and the Coase Theorem," Journal of Political Economy, 98, 1325-48.

Leblang, David (2000). "Political Uncertainty and Speculative Attacks," working paper, Department of Political Science, University of Colorado, Boulder.

McKinnon, Ron (2001). "The International Dollar Standard and Sustainability of the U.S. Current Account Deficit," Brookings Papers on Economic Activity 1, 227-240.

Tanzi, Vito and Hamid Davoodi (1997). "Corruption, Public Investment, and Growth," IMF working Paper WP/97/139, October.

Tversky, A. and D. Kahneman (1991) "Loss Aversion and Riskless Choice: A Reference Dependence Model," Quarterly Journal of Economics, 106, 1039-61. 
Data Appendix

rmg/usp $=$ reserves minus gold, deflated by the U.S. GDP deflator (1995=100). Source: International Financial Statistics (IMF) for the reserves data and World Economic Outlook (IMF) for the deflator.

lpop = total population, logged. Source: World Development Indicators.

$\operatorname{lgpc}=$ real GDP per capita, logged. Source: World Development Indicators.

lexa $=$ volatility of real export receipts, logged. Volatility is calculated using annual data and is the standard error of a regression of trend real exports. Source: International Financial Statistics.

limy $=$ the percentage share of imports in GDP, logged. Source: World Development Indicators.

lneer $=$ volatility of the nominal effective exchange rate, logged. Annual volatility is calculated using the previous 24 months of data and is the standard deviation of the innovation of the percentage change in the nominal effective exchange rate. Source: Information System Network, IMF.

corrupt $=$ corruption index is from Tanzi and Davoodi (1997). The index is spliced from two sources, Business International and International Country Risk Guide. Business International asks informed correspondents to measure the degree to which business transactions involved corruption or questionable payments. The index ranges from 0 (most corrupt) to 10 (least corrupt) and is available for the 1980-1983 period. International Country Risk Guide asks foreign investors to assess the extent to which high government officials will demand special payments or illegal payments are expected throughout the lower levels of government in the forms of bribes connected with import and export licenses, exchange controls, tax assessment, police protection, or loans. The index ranges from 0 (most corrupt) to 6 (least corrupt) and is available for the 1982-1995 period. It has been re-scaled by multiplying it by 10/6 so that both indexes range from 0 to 10 . Because the data change very little from year to year, 1995 values are used for 1996 observations. For ease in interpreting results, the index has been multiplied by minus one so that higher values of the index imply higher corruption.

pol $=$ the probability of a leadership change by constitutional means. Source: Leblang (2000).

Countries: The 137 countries listed in the World Bank's Global Development Finance. Note that Hong Kong, Singapore and Taiwan are not included in the GDF data set. 
Figure 1: Share of World Reserves Minus Gold
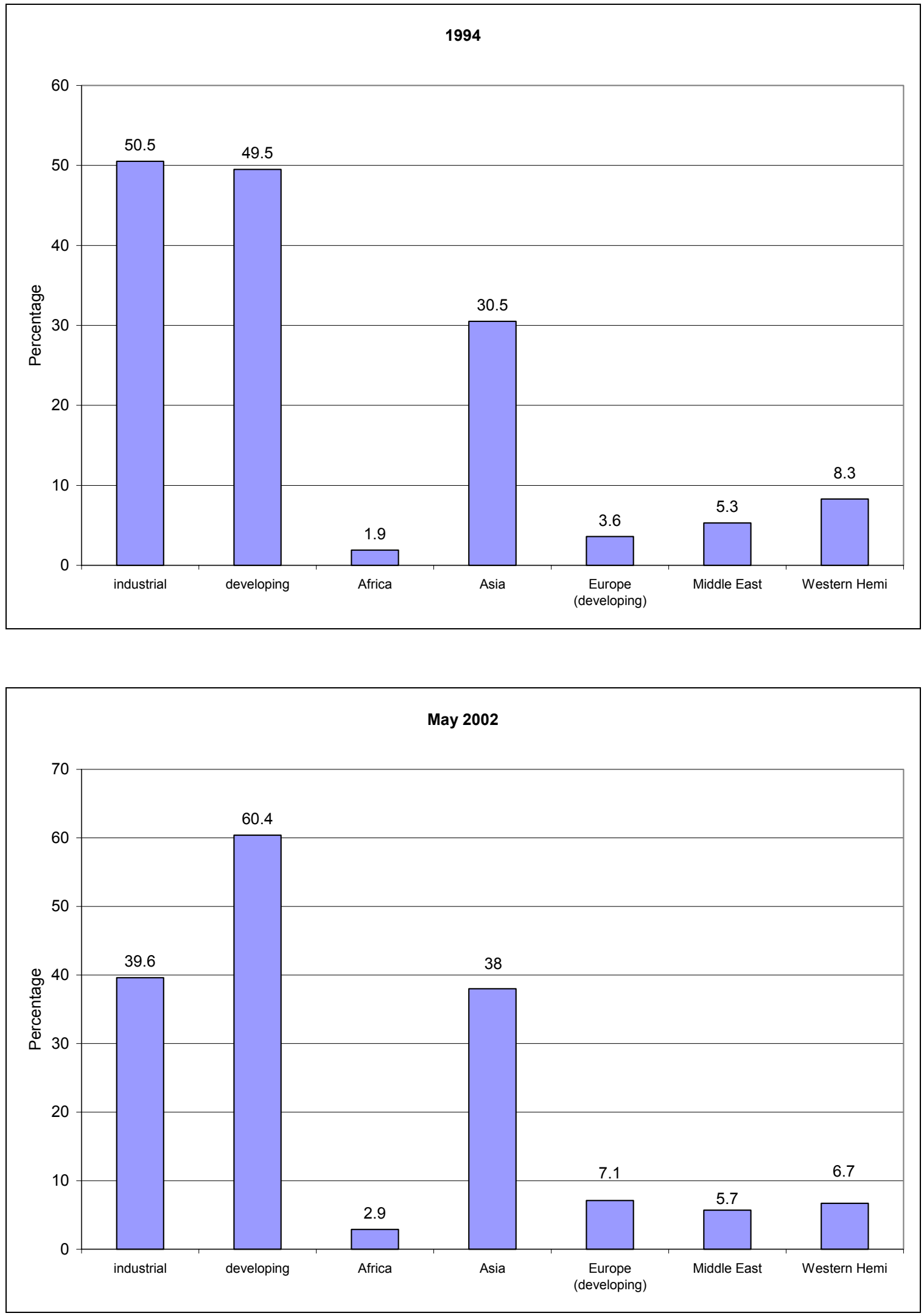


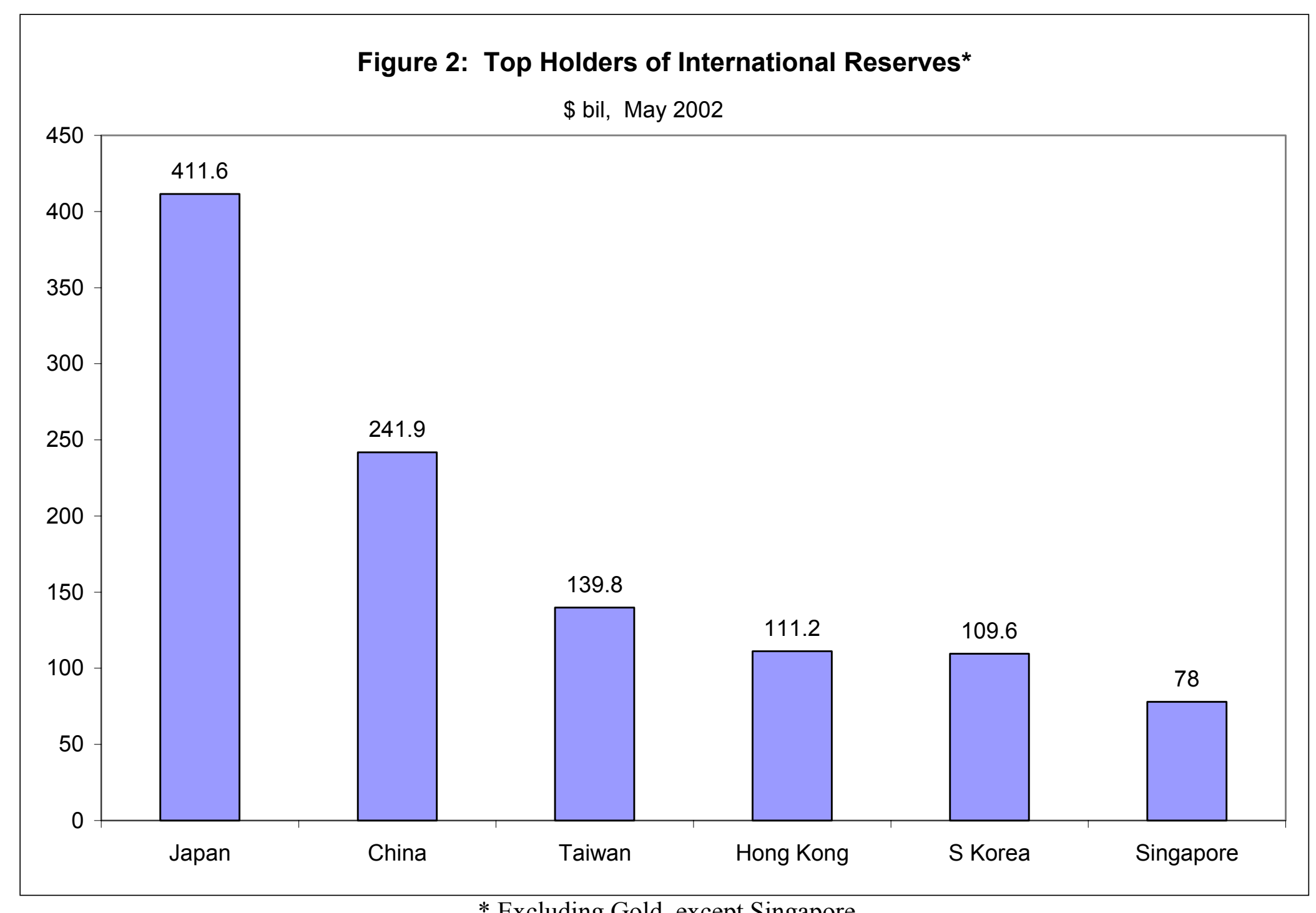

* Excluding Gold, except Singapore 
Figure 3: China's Reserve Holdings
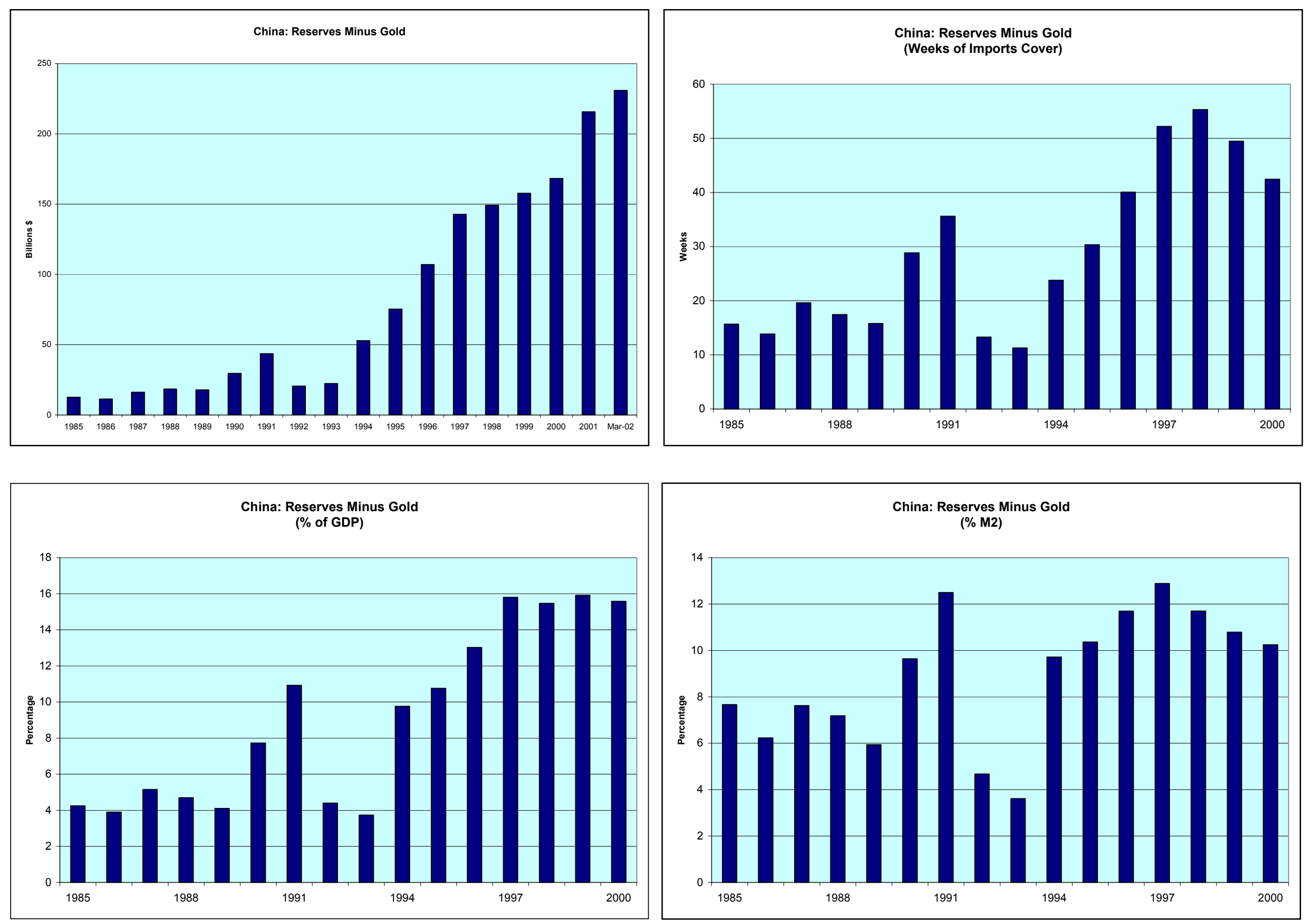

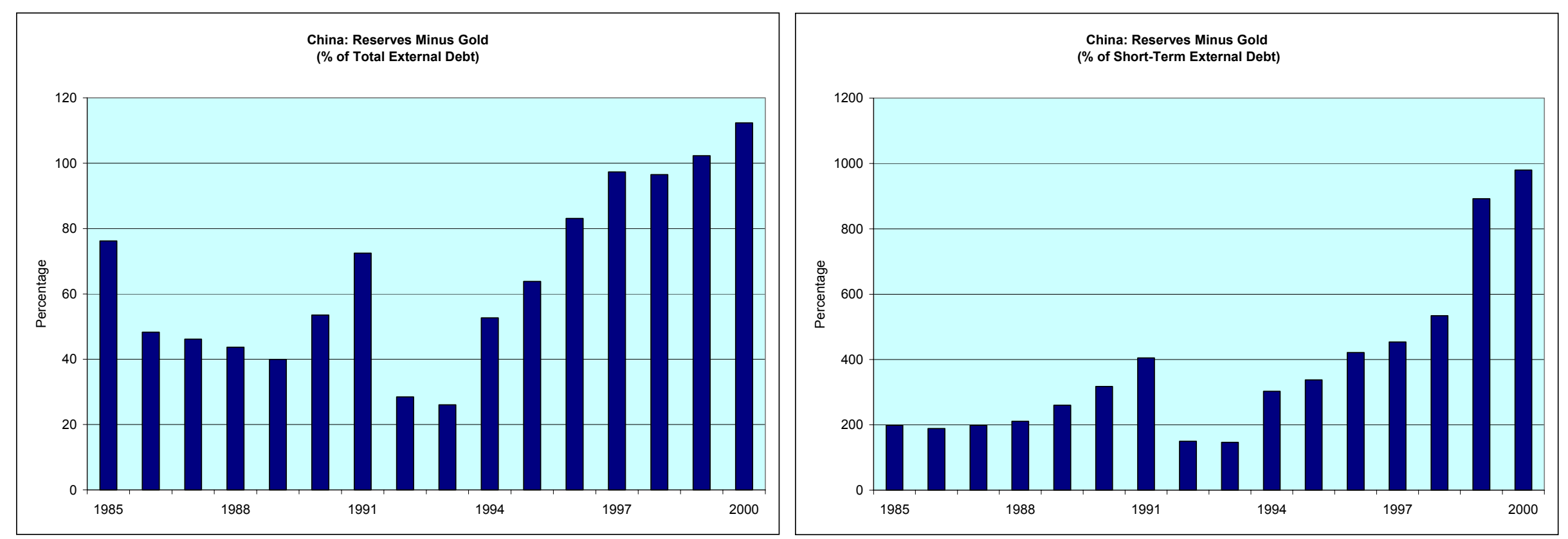
Figure 4: Taiwan's Reserve Holdings
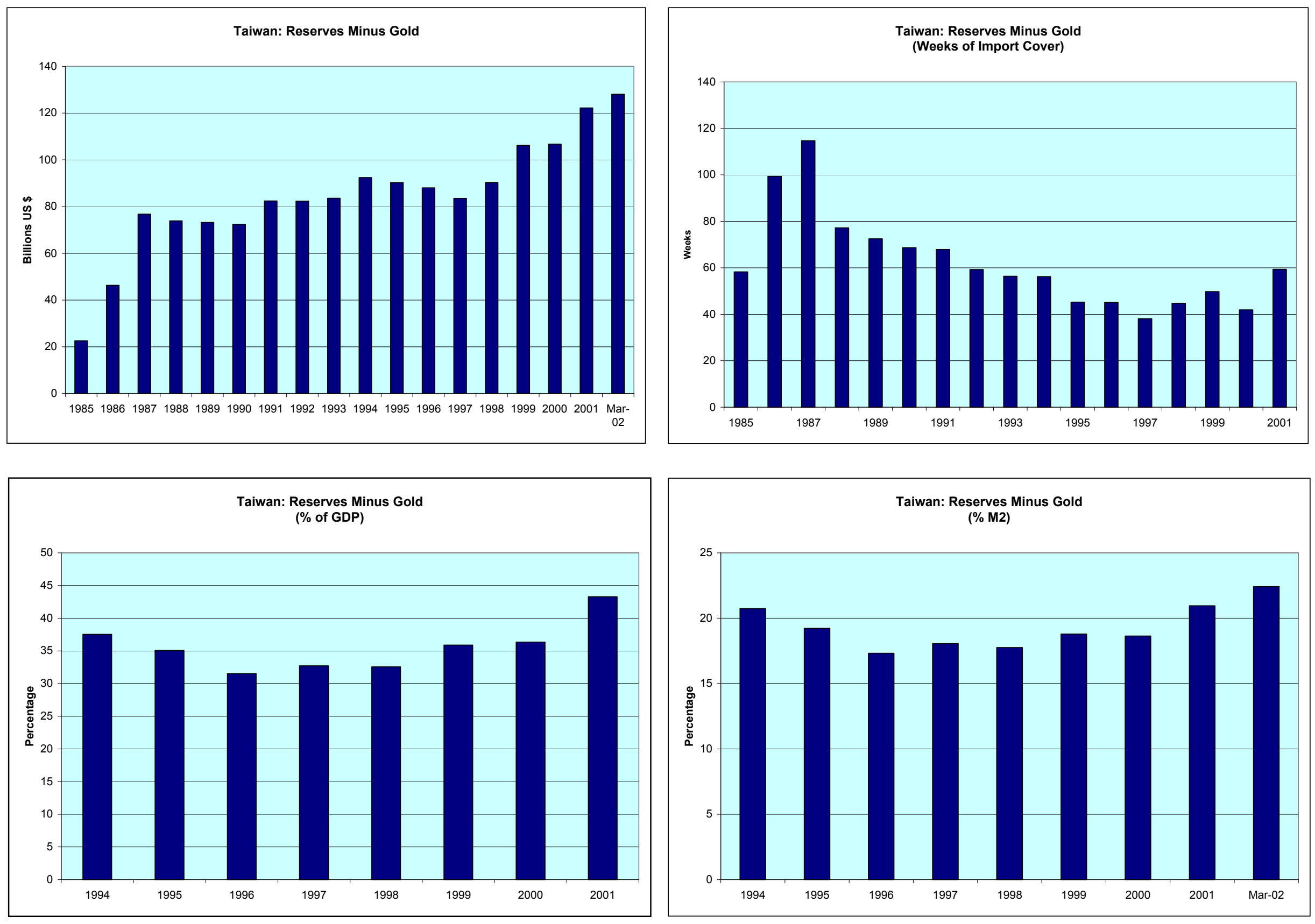
Figure 5: Hong Kong's Reserve Holdings
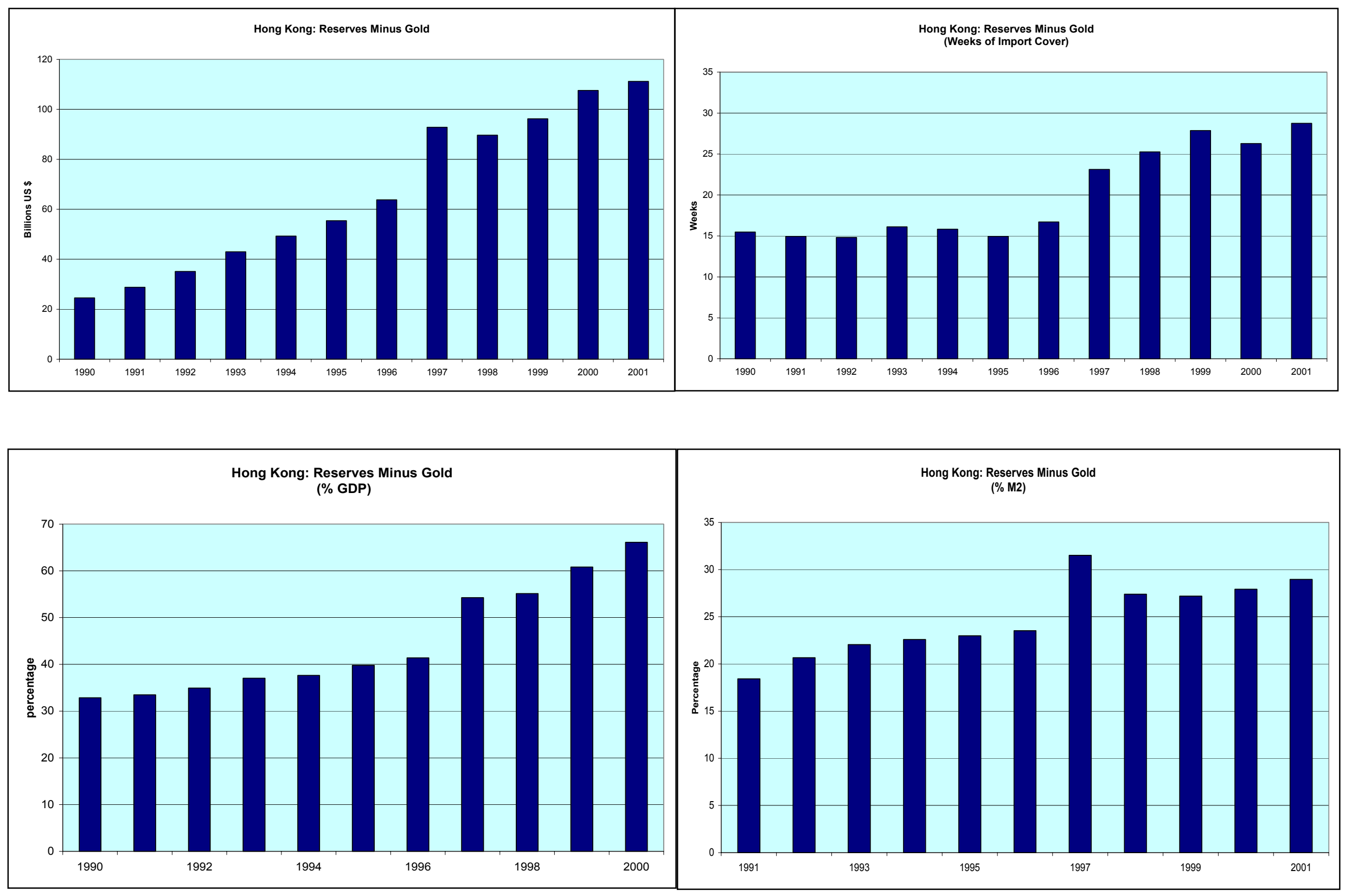
Figure 6: Korea's Reserve Holdings
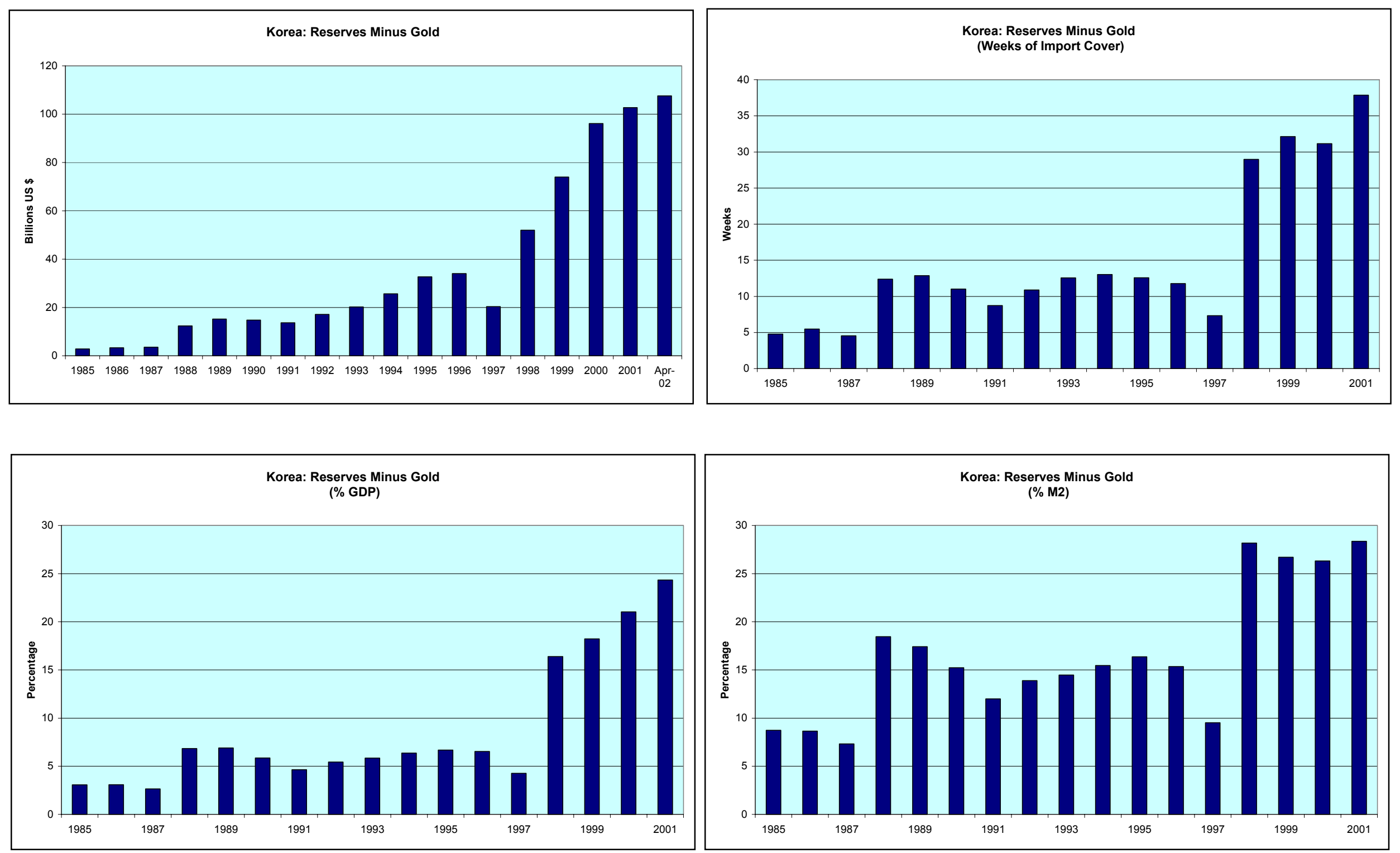

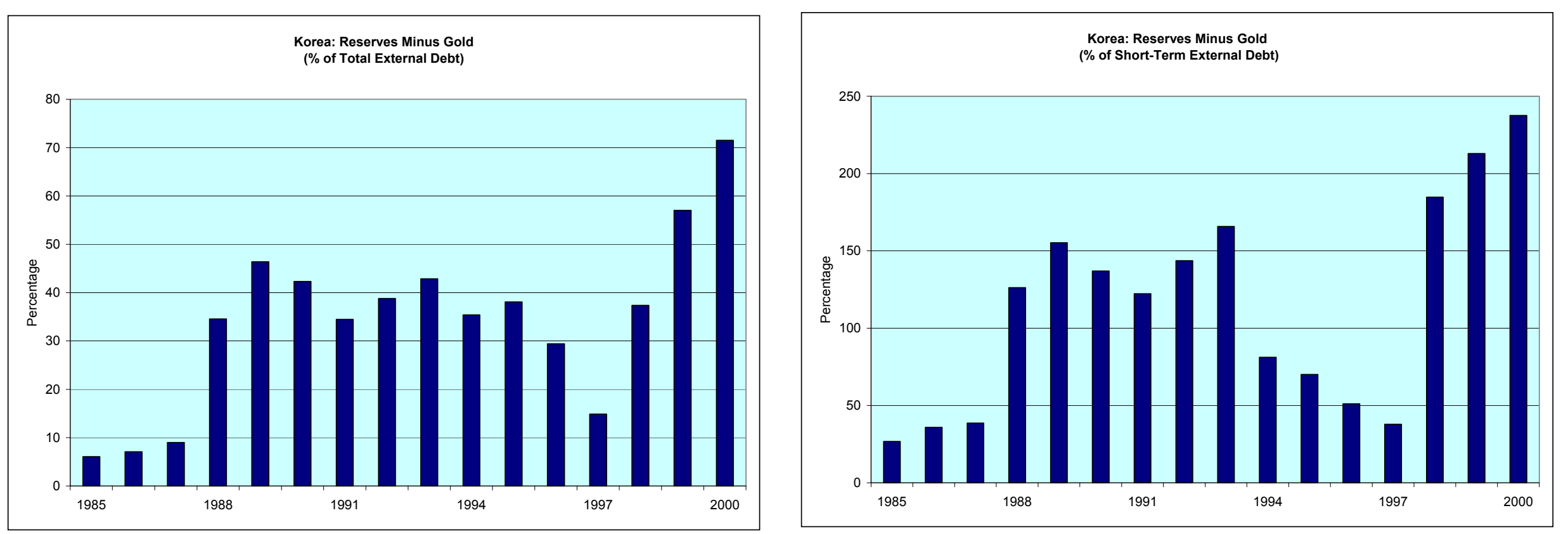
Figure 7: Singapore's Reserve Holdings
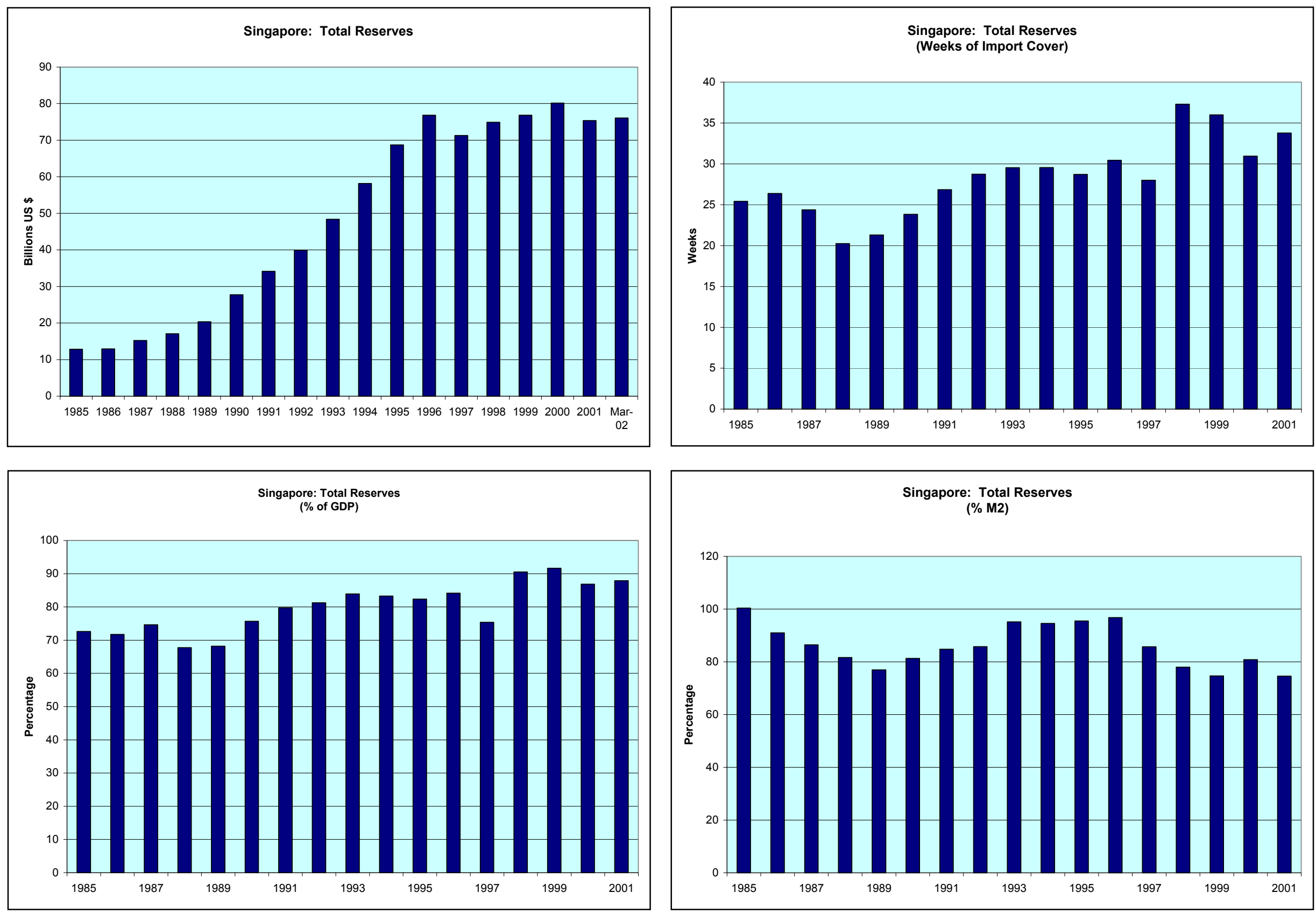

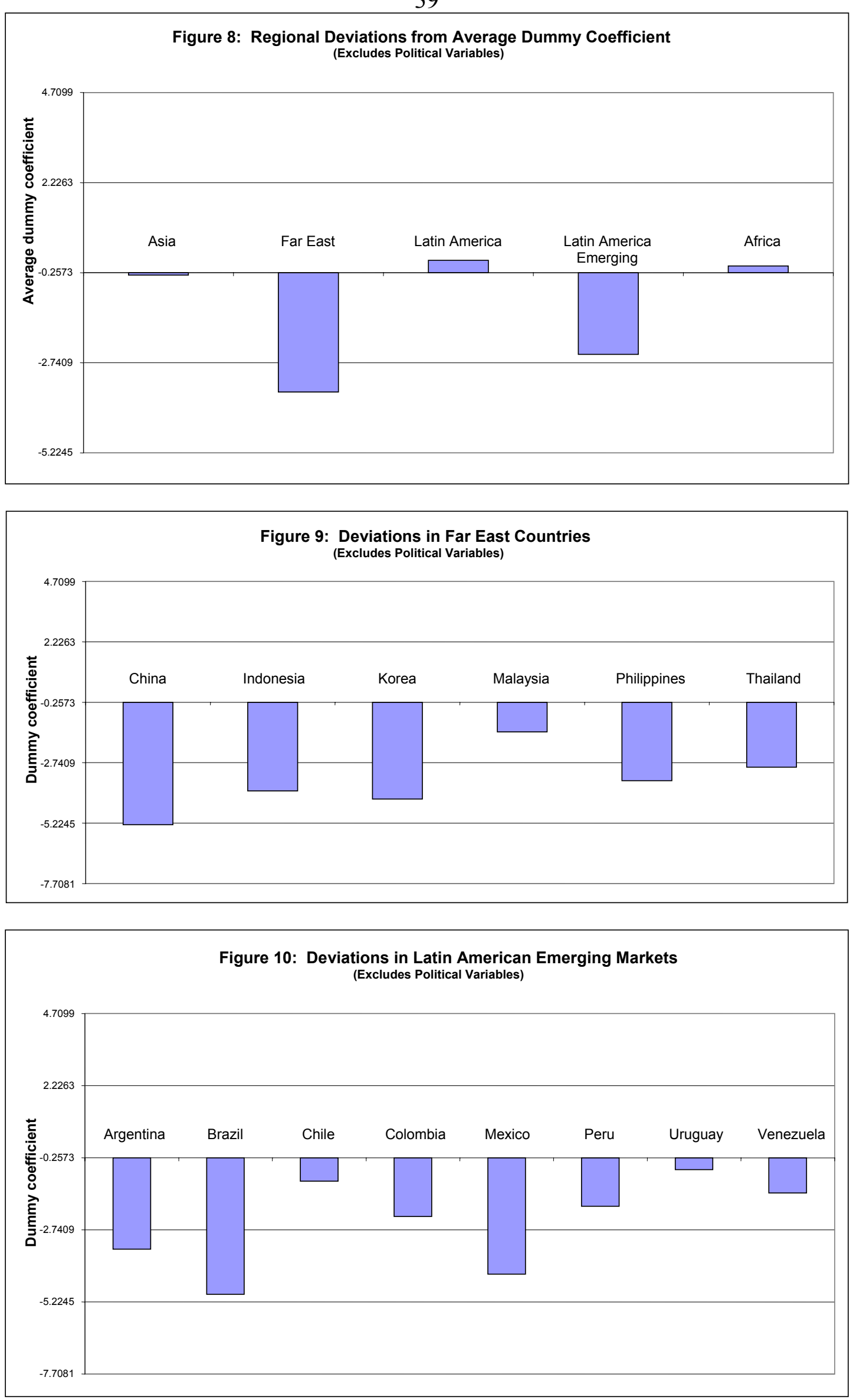

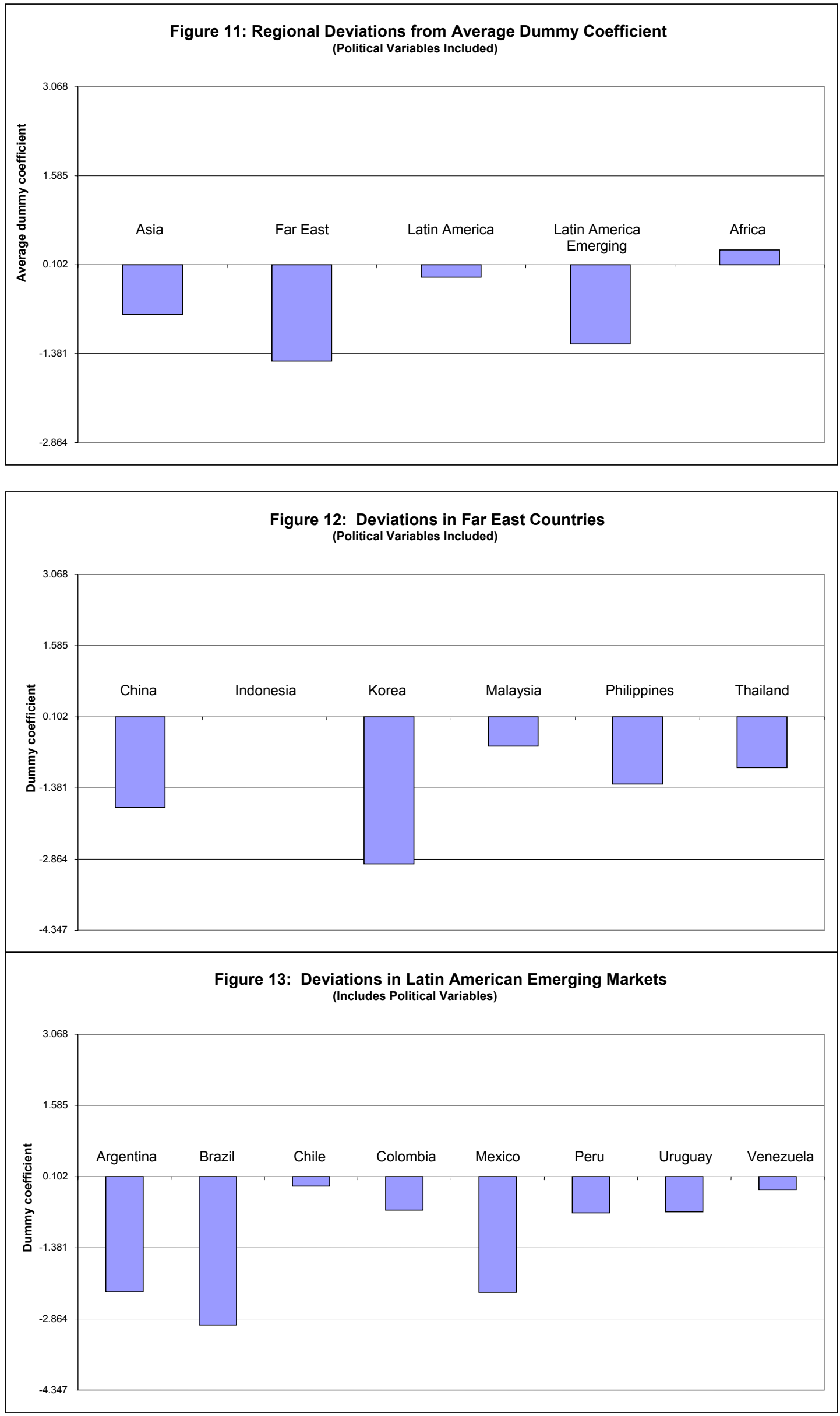
Figure 14: Deviation From Average Dummy Coefficient

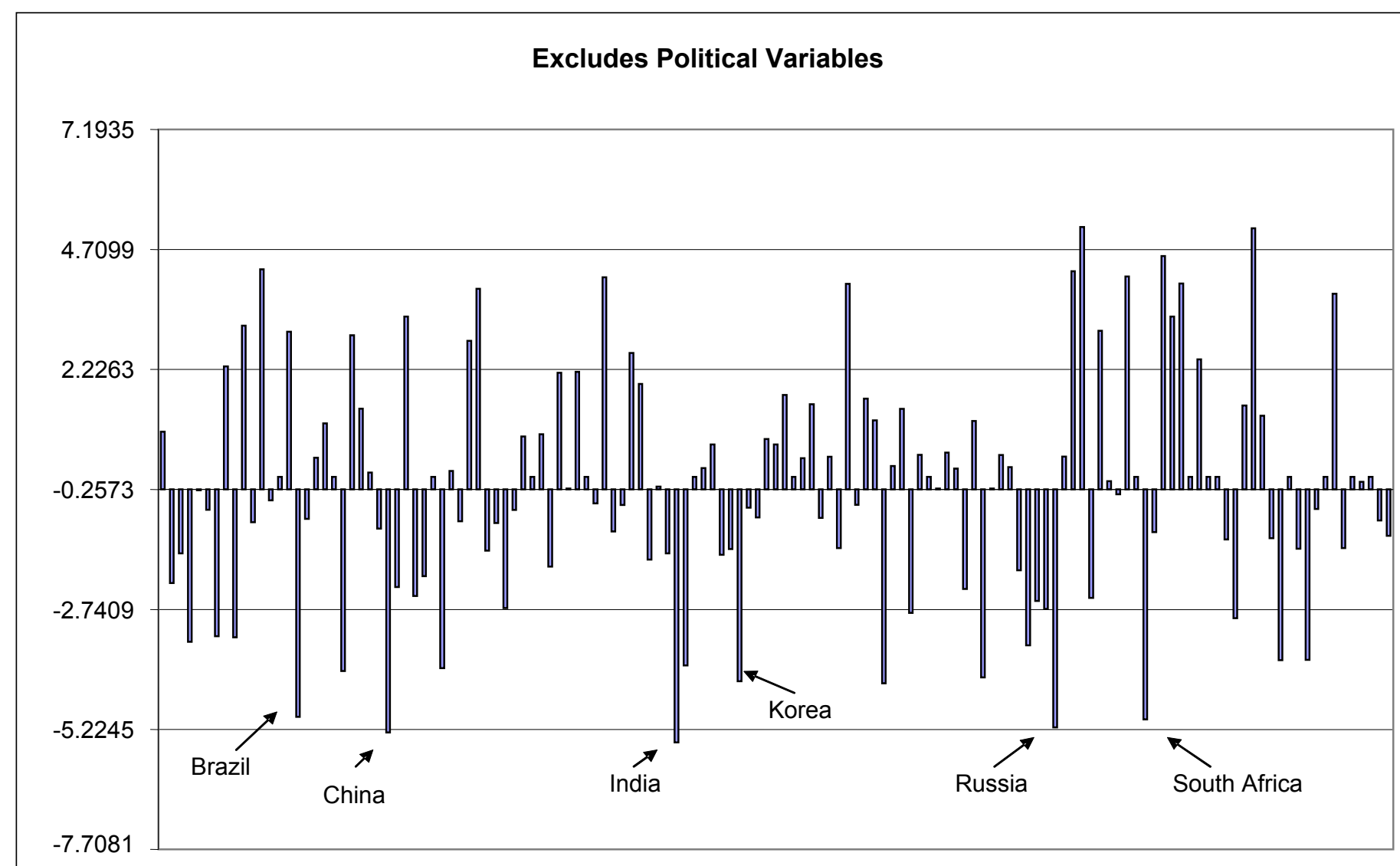

Includes Political Variables

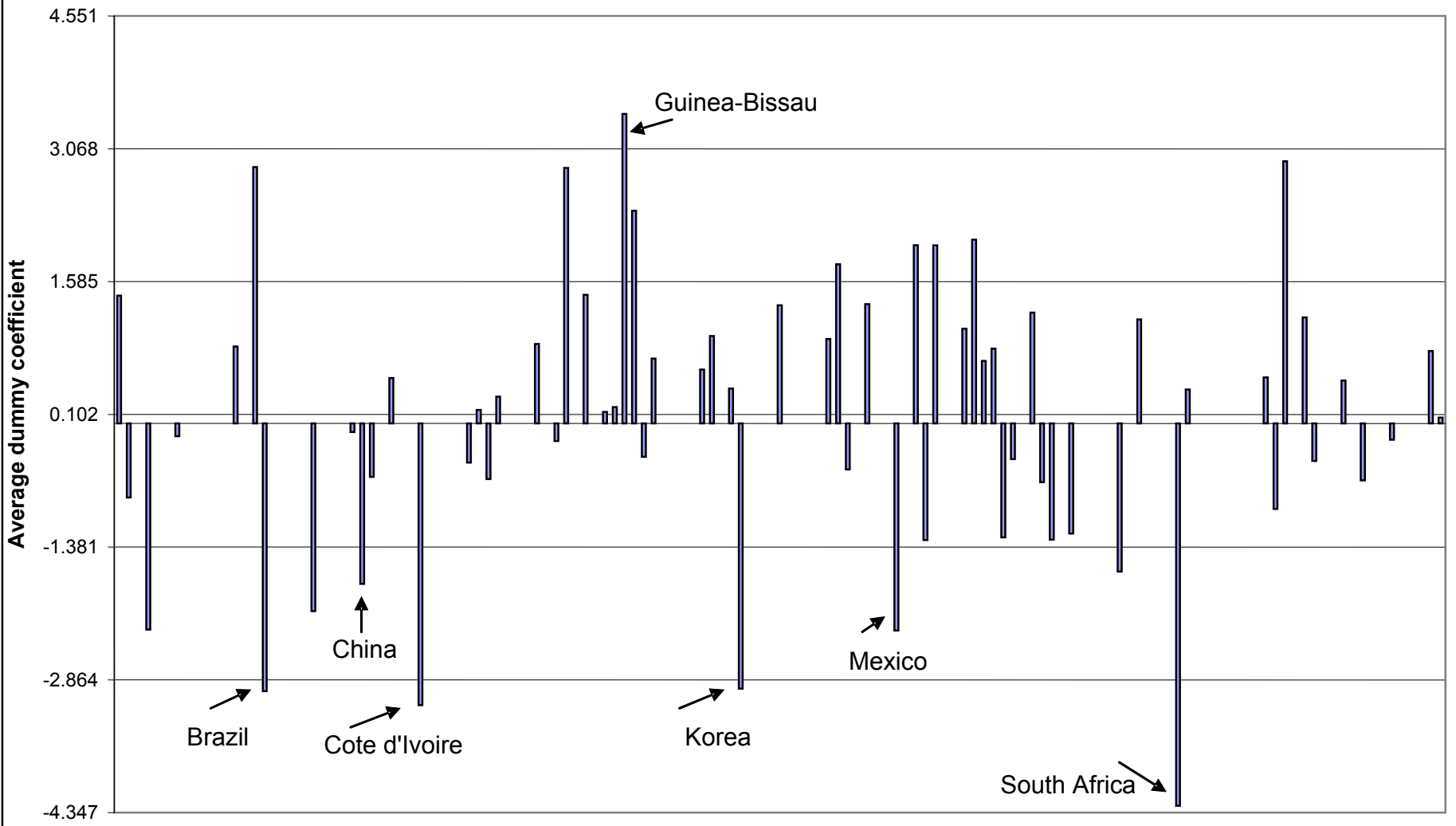


Figure 15

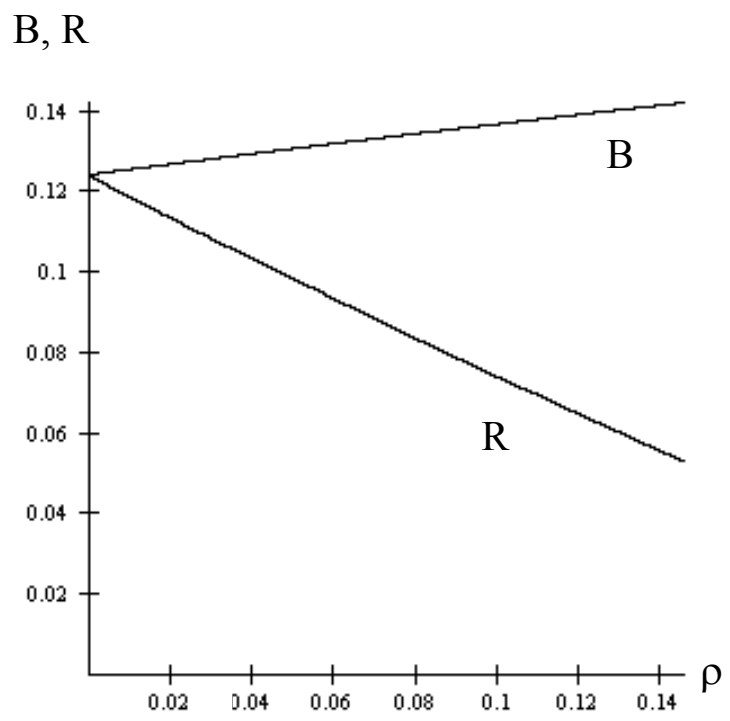

Optimal borrowing (B) and international reserves (R) as a function of the subjective rate of time preference. The Figure reports the values of $\mathrm{B}$ and $\mathrm{R}$ corresponding to

$$
r_{f}=0 ; \quad \bar{G}=0.06 ; \quad \alpha=0.14 ; \quad \varepsilon=0.2 ; \quad \lambda=0.7 .
$$




\section{Table 1: Determinants of Reserve Holdings}

(1)

obs
countries

dep var

lpop

$\operatorname{lgpc}$

lexa

limy

lneer

corrupt

pol

$\bar{R}^{2}$
1954

122

$\ln (\mathrm{R} / \mathrm{P})$

$2.1762 * *$

$(0.4607)$

$1.5436 * *$

(0.2878)

$0.2512 * *$

(0.1044)

$0.4954 * *$

(0.2020)

$-0.1065 * *$

(0.367)

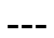

$---$

0.88
(2)

915

65

$\ln (\mathrm{R} / \mathrm{P})$

$1.6764 * *$

(0.6124)

$1.8111^{* *}$

(0.3633)

0.1176

(0.1456)

0.4976 **

(0.2675)

$-0.1092 *$

(0.0613)

$-0.1283 * *$

(0.0442)

$-0.2904 * *$

(0.1481)

0.88

Standard errors are corrected for heteroskedasticity and autocorrelation. All regressions include fixed country effects. Constant terms not reported. When regression (1) is rerun using the smaller sample of regression (2), lexa loses its significance and the $\bar{R}^{2}$ falls to 0.85 .

‘**' ('*’) indicates statistical significance at the 5 percent (10 percent) level.

Sample based on annual data over the 1980-1996 period for 137 developing countries listed in the World Bank's Global Development Finance. Sample size reduced because of data availability. Dependent variable is reserves minus gold in US\$ deflated by the US GDP deflator, logged. Explanatory variables are total population (logged), real GDP per capita (logged), the volatility of real export receipts (logged), imports of goods and services as a share of GDP (logged), the volatility of the nominal effective exchange rate (logged), an index of political corruption (scale $0-10$, with 10 being the most corrupt), and the probability of government change by constitutional means. 


\section{Table 2: Out-of Sample Forecast Error}

$\begin{array}{ccc} & \text { actual rmg/usp } & \text { predicted rmg/usp } \\ \text { KOREA } & (\$ \mathrm{bil}) & (\text { \$bil) } \\ 97 & 19.60519043 & 41.2493085 \\ 98 & 49.39624203 & 34.82217335 \\ 99 & 69.35403645 & 43.58418473\end{array}$

$$
\begin{gathered}
\text { actual-predicted } \\
\text { (\$bil) } \\
-21.64411807 \\
14.57406868 \\
25.76985171
\end{gathered}
$$

$$
\begin{gathered}
125.3781473 \\
130.360586 \\
160.1922008
\end{gathered}
$$

24.01609784

18.94962892

21.88571956

6.404522293

5.851888028

5.534185213

12.40158577

MALAYSIA

97

98

99
20.01004403

24.29096205

28.67295514
36.01171669

31.21548697

36.28826276
12.03806263

11.42618965

$-12.34129846$

1.183407094

8.444928222

10.04422751

2.915810523

6.867400556

$-16.00167266$

$-6.924524925$

$-7.615307615$
0.589769436 error

overpredicts underpredicts underpredicts

underpredicts underpredicts overpredicts

underpredicts underpredicts underpredicts

underpredicts underpredicts underpredicts

overpredicts overpredicts overpredicts 